\title{
The Hatillo Limestone, Pueblo Viejo district, Dominican Republic: Marginal reef or impermeable cap?
}

\author{
La Caliza Hatillo, distrito de Pueblo Viejo, República Dominicana: ¿Un arrecife marginal o \\ capa impermeable?
}

\author{
Carl E. Nelson ${ }^{1, *}$, José Polanco², Arturo Macassi ${ }^{2}$, Hugo Domínguez ${ }^{3}$, Joaquín A. Proenza ${ }^{4}$, \\ Lisard Torró ${ }^{5}$, David Rhys ${ }^{6}$, Manuel Iturralde-Vinent ${ }^{7}$
}

${ }^{1}$ Recursos del Caribe, S.A., 2360 23rd Street Boulder, 80304, Colorado, United States.

${ }^{2}$ Pueblo Viejo Dominicano Corp., Av. Lope de Vega No. 29, 10125, Santo Domingo, Dominican Republic.

${ }^{3}$ Barrick International Ltd., Av. Lope de Vega No. 29, Santo Domingo 10125, Dominican Republic.

${ }^{4}$ Departament de Mineralogia, Petrologia i Geologia Aplicada, Facultat de Ciencias de la Tierra, Universitat de Barcelona, 08028, Barcelona, Spain.

${ }^{5}$ Geological Engineering Program, Faculty of Sciences and Engineering, Pontifical Catholic University of Peru, 15088, Lima, Peru.

${ }^{6}$ Panterra GeoServices Inc., 14180 Greencrest Drive, Surrey, B.G., V4P 1L9, Canada.

Academia de Ciencias de Cuba, No.460 entre Amargura y Teniente Rey, Habana Vieja, 259, La Habana, Cuba.

* Corresponding author: (C. Nelson) carlericnelson@gmail.com

\section{How to cite this article:}

Nelson, C., Polanco, J., Macassi, A., Dominguez,H., Proenza, J., Torró, L., Rhys, D., Iturralde-Vinent, M., 2020, The Hatillo Limestone, Pueblo Viejo district, Dominican Republic: Marginal reef or impermeable cap?: Boletín de la Sociedad Geológica Mexicana, 72 (3), A011119. http://dx.doi.org/10.18268/ BSGM2020v72n3a011119

Manuscript received: May 2, 2019 Corrected manuscript received: October 21, 2019 Manuscript accepted: November 5, 2020

Peer Reviewing under the responsibility of Universidad Nacional Autónoma de México.

\section{ABSTRACT}

The Hatillo Limestone and the underlying Los Ranchos Formation are exposed over an east-west distance of $100 \mathrm{~km}$ in the eastern Dominican Republic. The lowermost portion of the Hatillo Limestone in the Pueblo Viejo district contains a Late Lower Albian fossil assemblage including corals and rudist bivalves indicative of a near-shore reef environment. Diamond drilling in the Pueblo Viejo district and exposures in the open pits show that the Hatillo Limestone conformably overlies the Early Cretaceous Los Ranchos Formation. Volcanogenic massive sulfide beds, exposed in the Moore pit, provide evidence for an Early Cretaceous, syn-mineralization paleosurface. Altered and mineralized clasts in the epiclastic, sedimentary host-rock section at the Pueblo Viejo mine indicate that the ore deposits were open to erosion during hydrothermal alteration and mineralization. The Hatillo Limestone did not overlie the ore deposits during the mineralizing event and, consequently, could not have acted as an impermeable cap to ascending hydrothermal fluids. Intra-oceanic island arc volcanism (Los Ranchos Formation) overlapped at the Aptian-Albian boundary $(112 \mathrm{Ma})$ with a marginal fringing reef (basal Hatillo Limestone). The marginal reef gradually gave way to deeper-water facies as Hatillo Limestone deposition progressed through the middle Albian. Low-angle reverse faulting, penetrative deformation, and metamorphic recrystallization affected the Hatillo Limestone as well as the Los Ranchos and Maimón formations during the Late Cretaceous. Deformation intensity and metamorphic grade progressed from incipient metamorphism in the Pueblo Viejo district to schists in the Maimón Formation to amphibolite near a faulted contact with the Loma Caribe peridotite.

Keywords: Garibbean tectonics, Early Gretaceous unconformity, Los Ranchos Formation, Gretaceous metamorphism, arc polarity reversal.

\section{RESUMEN}

La Caliza Hatillo y la subyacente Formación Los Ranchos están expuestas sobre una distancia este-oeste de $100 \mathrm{~km}$ en el oriente de la República Dominicana. La porción más inferior de la Caliza Hatillo en el distrito de Pueblo Viejo contiene un ensamblaje de fósiles del Albiano inferior tardío incluyendo corales y rudistas bivalvos indicativos de un ambiente arrecifal cercano a la costa. Perforaciones diamantinas en el distrito de Pueblo Viejo y exposiciones en los tajos abiertos muestran que la caliza sobreyace conformablemente la Formación Los Ranchos del Cretácico Temprano. Capas de sulfuros masivos volcanogénicos en el tajo Moore proveen un punto fijo de referencia de una paleosuperficie contemporánea a la mineralización del Cretácico Temprano. Clastos alterados y mineralizados en la encajante secuencia epiclástica de la Formación Los Ranchos indican que los depósitos auriferos estaban abiertos a la erosión mientras la alteración hidrotermal y mineralización estaban en proceso. La Caliza Hatillo no cubrió los depósitos auriferos durante el proceso de mineralización y, como consecuencia, no hubiera podido actuar como una capa impermeable a fluidos hidrotermales. Volcanismo de arco de isla intraoceanico (la Formación Los Ranchos) se sobrelapó temporalmente en la frontera AptianaAlbiana (112 Ma) con un arrecife marginal (la base de la Caliza Hatillo). El arrecife marginal gradualmente dio paso a facies de aguas más profundas según progresó la deposición de la caliza. Fallamiento de bajo ángulo, deformación penetrativa y metamorfismo afectó la Caliza Hatillo además de las formaciones Los Ranchos y Maimón durante el Cretácico Tardio. La intensidad de la deformación y el grado de metamorfismo progresó de metamorfismo incipiente en el distrito de Pueblo Viejo a esquistos en la Formación Maimón hasta anfibolita cerca al contacto de falla con la peridotita Loma Caribe.

Palabras clave: Placa tectónica del Caribe, inconformidad Cretácico Temprano, Formación Los Ranchos, metamorfismo Cretácico, inversión de polaridad de arco. 


\section{Introduction}

The Hatillo Limestone extends in an east-west belt for over $100 \mathrm{~km}$ across the eastern Dominican Republic (Figure 1) where it crops out along the southern margin of the Los Ranchos Formation, a tholeiitic, intra-oceanic island arc of Early Cretaceous age (Kesler et al., 2005; Escuder-Viruete et al., 2007; Torró et al., 2017a, 2017b). This paper presents new observations from the Pueblo Viejo open pits, new geochemical data from diamond-drill holes and new results from district-scale geologic mapping that bear on the role of the Hatillo Limestone in tectonic models for the evolution of the Caribbean region as well as in genetic models for the development of Au-Ag-Cu deposits of the Pueblo Viejo district (Figure 1).

\section{The Hatillo Limestone}

The Hatillo Limestone is a massive, light- to medium-gray, biogenic limestone of late Aptian to middle Albian age. Bowin (1966) named the unit for exposures near the town of Hatillo (Figure 2) and described "a shallow water marine deposit of Early Cretaceous age.” Russell and Kesler (1991) described the Hatillo Limestone as composed of a basal conglomerate overlain by sandstone followed by calcareous sandstone and mudstone with abundant marine fossil fragments and, finally, by "typical massive reef limestone." Myczynski and Iturralde (2005) described "basal conglomerate, sandstones and calcareous sandstones covered by massive biogenic limestone" and referred to the Rio Hatillo Formation as having been, "deposited
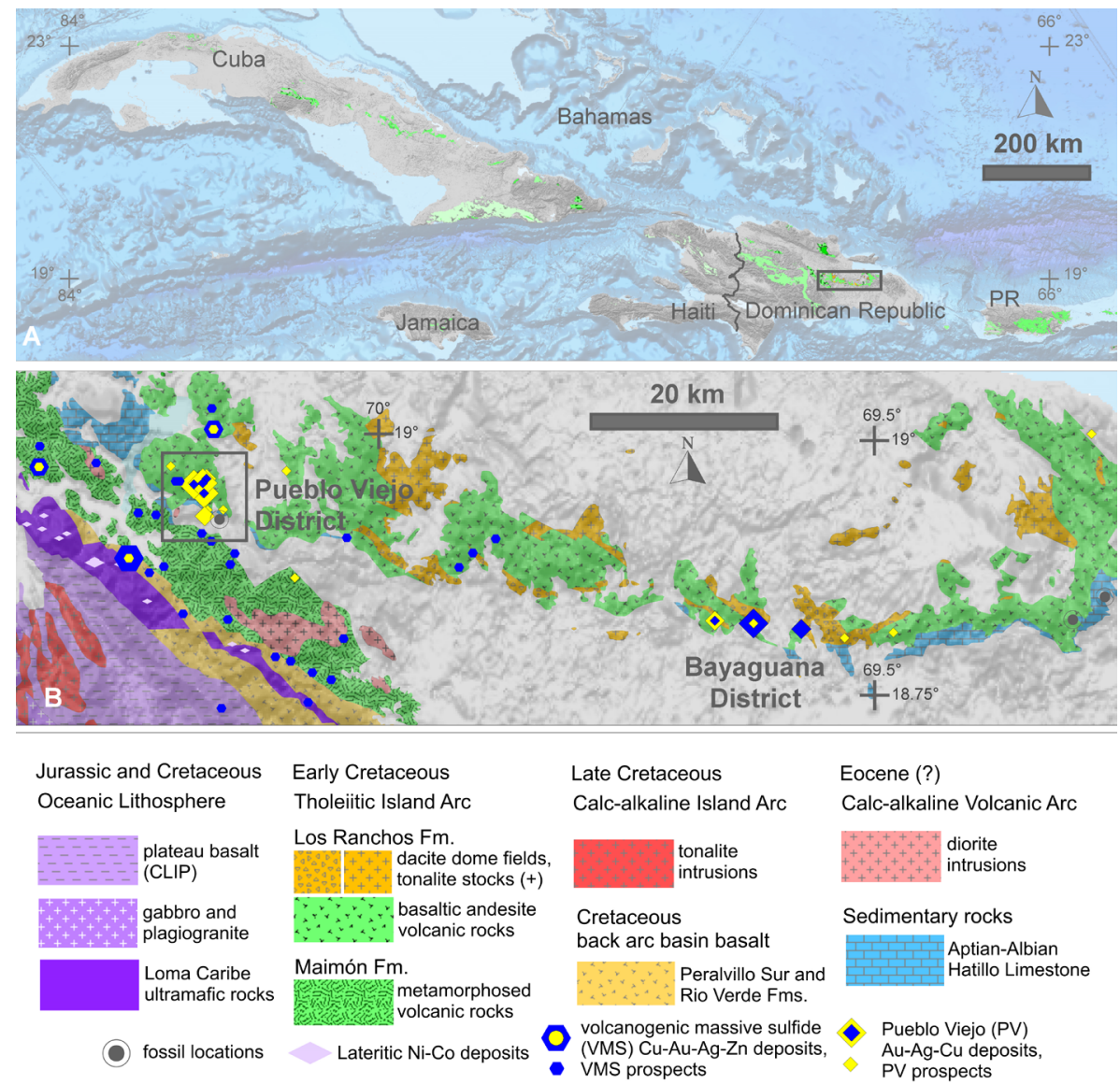

Late Cretaceous Eocene (?)

Calc-alkaline Island Arc Calc-alkaline Volcanic Arc

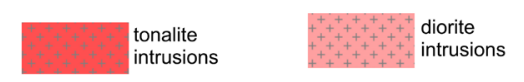

Cretaceous back arc basin basalt Peralvillo Sur and Rio Verde Fms.

Sedimentary rocks

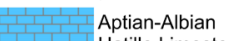
Hatillo Limestone

volcanogenic massive sulfide (VMS) Cu-Au-Ag-Zn deposits, VMS prospects

Pueblo Viejo (PV) Au-Ag-Cu deposits PV prospects

Figure 1 Location maps. (A) Distribution, in green, of Cretaceous, tholeiitic, intra-oceanic island arc volcanic rocks across the Greater Antilles including Cuba, Jamaica, Haiti, the Dominican Republic and Puerto Rico (PR). The gray box shows the location of Figure $1 \mathrm{~B}$. (B) Regional geologic map from Escuder-Viruete et al. (2007) showing the distribution of Hatillo Limestone in the Dominican Republic along with metallic mineral deposits and occurrences. Gray box shows the location of Figure 2. CLIP; Caribbean large igneous province. 
in a shallow, near-shore environment as part of the Cretaceous volcanic arc sections."

\subsection{LITHOLOGY}

Bonilla-Rodríguez (2014) studied the Hatillo Limestone along its entire $100 \mathrm{~km}$ strike length. He described a $64.7 \mathrm{~m}$ section from drill hole T-82 in the Pueblo Viejo District (Figure 2) that includes $6.1 \mathrm{~m}$ of basal, near-shore calcarenites and interbedded calcareous sandstone and marly limestone. The basal limestone contains fragments of corals and Aptian-Albian rudist bivalves. It is overlain by $13 \mathrm{~m}$ of near-shore to shallow-water packstones to grainstones with skeletal rudists, corals, and enchinoids. Representative photos of the basal Hatillo Limestone are shown in Figures 3A and $3 \mathrm{~B}$. Above this near-shore section there is 9.9 $\mathrm{m}$ of marly limestone with orbitolinid foraminifera, gastropods, and sponges overlain by $38.4 \mathrm{~m}$ of a deeper-water, lime-mudstone lithofacies with planktic constituents and scarce macrofossils. A representative photo of the deeper-water, massive Hatillo Limestone is shown in Figure 3C. The same Aptian-Albian rudist assemblage is found in the Encino and Vallecitos formations of Mexico, the Glen Rose Limestone of Texas, the Rio Matón Limestone of Puerto Rico, the Seafield Formation of Jamaica, and the Provincial Formation of Cuba (Bonilla-Rodríguez, 2014). Bonilla-Rodriguez et al. (2014) assigned the Hatillo Limestone to a latest Aptian to Albian, Caribbean carbonate platform "developed on the flank of the Los Ranchos volcanic core in response to sea level rise."

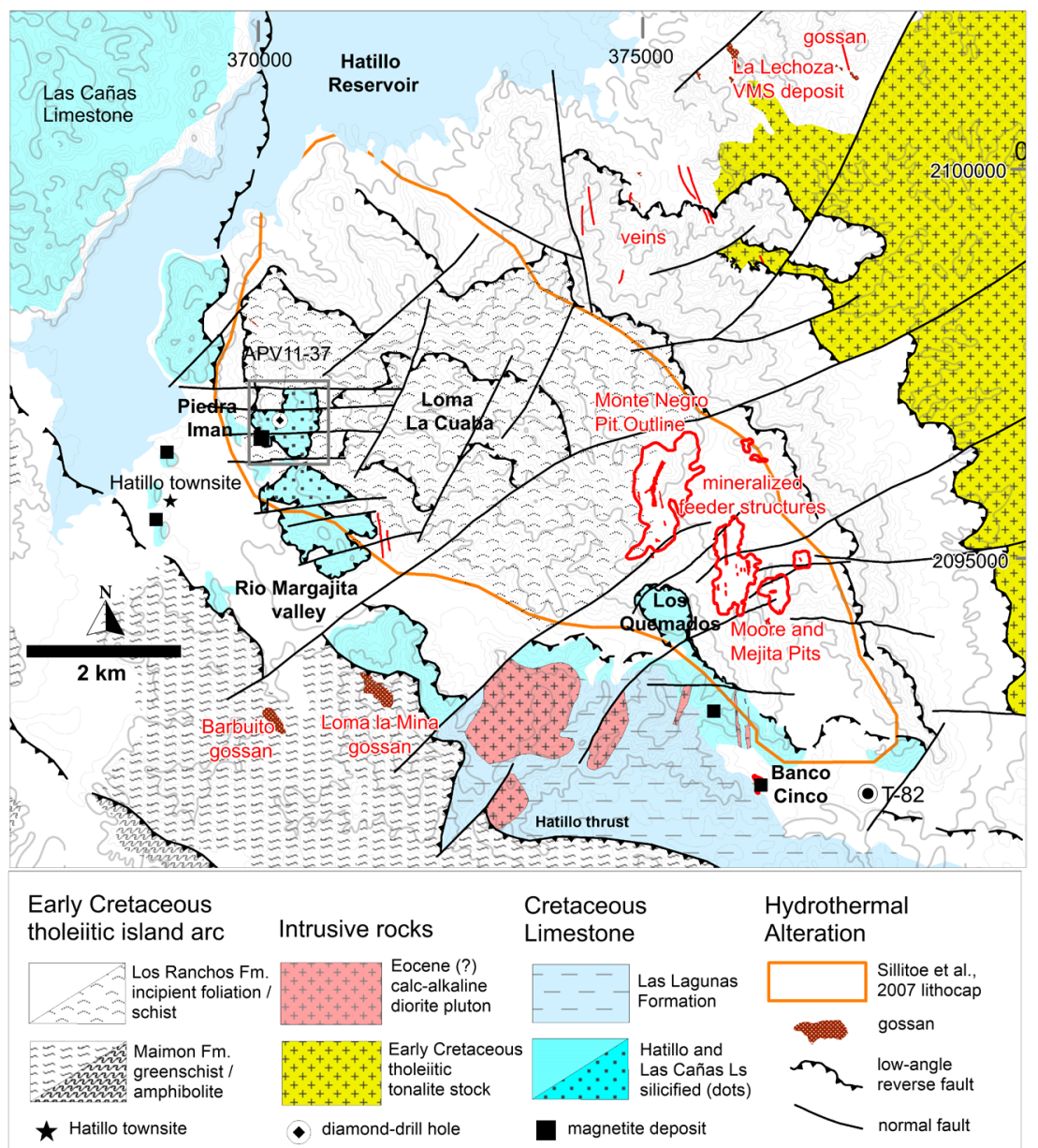

Figure 2 Geologic map showing locations mentioned in the text. A reported contact between the Hatillo Limestone (east of the Hatillo reservoir) and the Las Cañas Limestone (west of the Hatillo reservoir) is covered by the reservoir; gray box shows the location of Figure $7 A$ and $7 B$. VMS; volcanogenic massive sulfide. 
The Hatillo Limestone is overlain by massive limestone of the Las Cañas Limestone. An unconformity reported by Bowin (1966) between these two lithologically similar limestones is now covered by the Hatillo Reservoir (Figure 2). Iturralde-Vinent (1997) reported a late Albian age for the Las Cañas Limestone based on field examination and a fossil assemblage described by Koschmann and Gordon (1950). The Hatillo Limestone and the Las Cañas Limestone are overlain by argillites and sandy argillites of the Late Gretaceous Las Lagunas Formation.

\subsection{BASAL CONTACT}

Bowin (1966, figs. 1, 2 and p. 37) described the contact between the Hatillo Limestone and the underlying Los Ranchos Formation as conform- able and locally offset by faults. Russell and Kesler (1991) described the same contact as a residual paleosurface marked by a basal conglomerate and sandy sedimentary rocks reflecting a period of erosion prior to deposition of the Hatillo Limestone. The proposed unconformity and inferred period of uplift and erosion have often been cited as evidence for an Early Cretaceous tectonic event in the Greater Antilles (e.g., Lebron and Perfit, 1993; Draper et al., 1996; Pindell et al., 2005).

The contact of the Hatillo Limestone with the underlying Los Ranchos Formation is locally exposed in the Los Quemados quarry (Figure 2) where it is conformable (Figure 3A and 3B). In the Banco Cinco area (Figure 2), the contact is also conformable and is occupied by a conglomerate composed of rounded to sub-rounded, hydro-
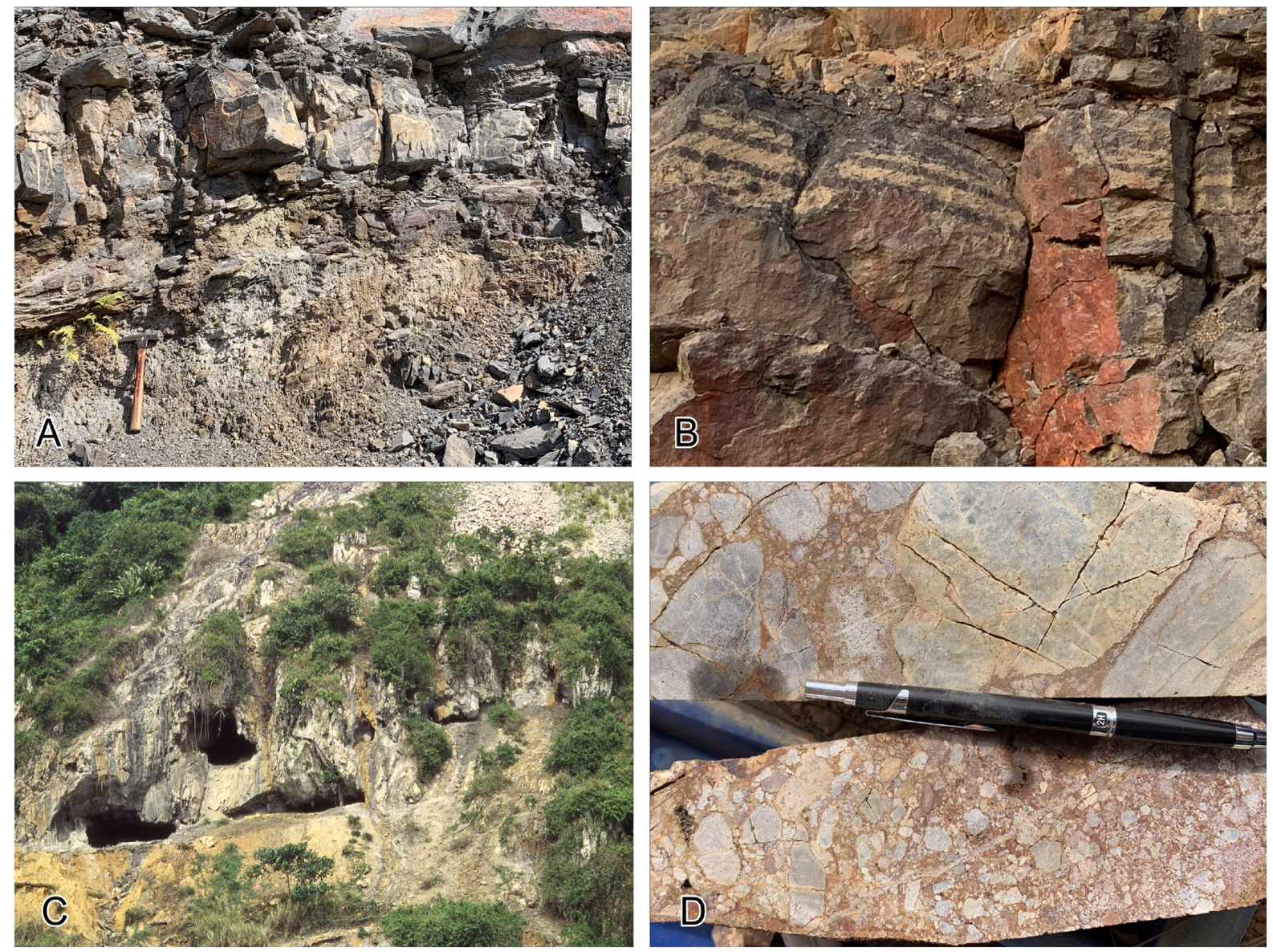

Figure 3 The Hatillo Limestone in the Pueblo Viejo mining district. (A) Basal limestone beds, Los Quemados. (B) Black bedded limestone from near the base of the Hatillo Limestone, Los Quemados, $4 \mathrm{~m}$ across the photo. (C) Massive limestone with karst cavities, south of Banco Cinco. (D) Hydrothermally altered basal conglomerate with hydrothermally altered clasts from a depth of $11 \mathrm{~m}$ in drill hole DPV17-520 near Banco Cinco. 
thermally altered clasts in a clast-supported and hydrothermally altered matrix (Figure 3D).

Geologic mapping and mineral exploration outside of the Pueblo Viejo mine area provides additional evidence for a conformable contact at the base of the Hatillo Limestone. In the Rio Margajita valley (Figure 2), Sillitoe et al. (2006) reported that "the carbonaceous siltstone at the top of the Los Ranchos Formation is transitional upward into typical Hatillo limestone." A transitional contact can also be observed in the Bayaguana district, $60 \mathrm{~km}$ east of the Pueblo Viejo district (Figure 1), where massive gray limestone is interbedded with carbonaceous siltstone. The epiclastic sedimentary basin in the Bayaguana district is much larger but very similar in terms of both age and geologic setting to the epiclastic sedimentary basin in the
Pueblo Viejo district (Nelson et al., 2011; Torró et al., 2017b).

Nelson (2000), Borst et al. (2012), Evans et al. (2014), and Cardenas et al. (2018), based on diamond-drill holes, open-pit exposures, and outcrop mapping across the Pueblo Viejo district, reported offset of the contact between the Hatillo Limestone and the underlying Los Ranchos Formation by low-angle reverse faults. Low-angle slickensided fault surfaces can be observed in the pits at Pueblo Viejo, at the Los Quemados quarry, on Loma la Guaba, and in outcrop exposures across the Pueblo Viejo district (Figure 2). Representative photos of low-angle reverse faults, including faults that offset the contact between the Los Ranchos Formation and the Hatillo Limestone, are shown in Figure 4.
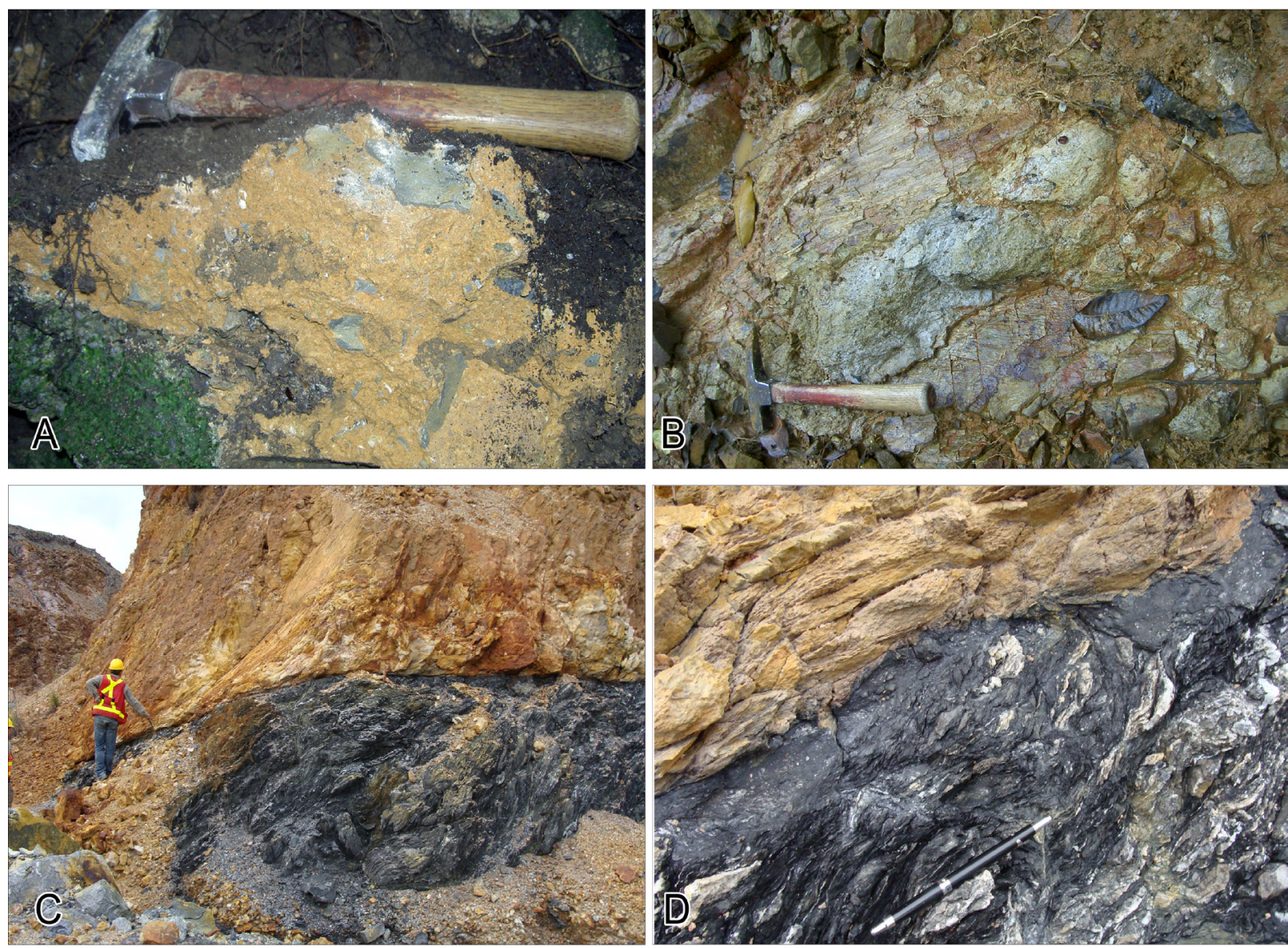

Figure 4 Photos of low-angle reverse faults at the base of the Hatillo Limestone (A, B) and from the Los Ranchos Formation at the south end of the Monte Negro pit (C, D). (A) Fault breccia with angular limestone fragments, Los Quemados. (B) Slickensided, low-angle fault surfaces, Los Quemados. (C) Schist (above) in low-angle reverse fault contact with carbonaceous epiclastic sedimentary rocks (below). (D) Close-up, showing fault gouge, of low-angle reverse fault shown in (C). 


\subsection{AGE}

Bowin (1966) proposed an Aptian-Albian age for the Hatillo Limestone based on fossils from a single (unrecorded) location. Mycynski and Iturralde (2005) provided evidence for a late early Albian age based on ammonites collected from the lower portion of the Hatillo Limestone at the Pueblo Viejo mine. Samples collected by Bonilla-Rodríguez et al. (2014) from diamond drill hole T-82 (Figure 2) and from two locations at the extreme eastern end of the belt of Hatillo Limestone (Figure 1) also revealed an Aptian-Albian fossil assemblage. The age assignment is based principally on Coalcamana-Caprinuloidea rudist bivalves from the lower portion of the Hatillo Limestone. Orbitolinid foraminifers reported by Bonilla-Rodríguez et al. (2014) from higher in the Hatillo Limestone section indicate that deposition continued into the middle Albian.

The age of the Hatillo Limestone as derived from fossil assemblages is in close agreement with the age derived from isotopic analysis. Bonilla-Rodríguez (2014) reported strontium isotope $\left({ }^{87} \mathrm{Sr} /{ }^{86} \mathrm{Sr}\right)$ analyses for six rudist shell samples from the Hatillo Limestone. The derived mean age for the lower portion of the Hatillo Limestone, based on the Lower Cretaceous reference curve of McArthur et al. (2001), was 112.79 Ma with values ranging from 112.43 to $113.15 \mathrm{Ma}$ at a precision of $0.93 \mathrm{Ma}$.

\section{The Los Ranchos Formation}

Torró et al. (2016, 2017a), summarizing published $\mathrm{U}-\mathrm{Pb}$ radiometric dates from multiple sources, placed the initiation of tholeiitic, intra-oceanic island arc volcanism in Cuba and Hispaniola at 126 to $123 \mathrm{Ma}$, after the onset of Proto-Caribbean subduction at 136 to $130 \mathrm{Ma}$. Escuder-Viruete $e t$ al. (2006) reported U-Pb zircon ages of $116.0 \pm$ $0.8 \mathrm{Ma}$ for a sample of Los Ranchos rhyodacite from the Bayaguana district (Figure 1) and 115.5 $\pm 0.3 \mathrm{Ma}$ for geochemically similar tonalite that intrudes the Los Ranchos Formation (Figure 2). Volcanism in the Los Ranchos Formation continued to $\sim 109 \mathrm{Ma}$ according to Mueller et al. (2008) and Torró et al. (2017a) who reported U-Pb ages of $109.6 \pm 0.6 \mathrm{Ma}$ and 108.4 $\pm 1.2 \mathrm{Ma}$, respectively, from a prominent basaltic andesite dike exposed in both the Moore and Monte Negro pits (Figure 2). These U-Pb ages, substantially younger than the near-shore reef assemblages described above from basal portions of the Hatillo Limestone, indicate that limestone deposition overlapped with volcanism during a period of roughly 4 million years $(\sim 109$ to $\sim 113 \mathrm{Ma})$.

The overlap between radiometric dates for the Los Ranchos Formation and the age of fossil assemblages from the Hatillo Limestone is supported by field evidence. Sillitoe et al. (2007), based on diamond drilling at the Loma la Mina gossan (Figure 2), reported andesitic tuff within but near the base of the Hatillo Limestone. Borst et al. (2012), Evans et al. (2014), and Cardenas et al. (2018) reported pyroclastic basaltic andesite from the base of the Hatillo Limestone at the Pueblo Viejo mine.

\section{Pueblo Viejo Ore Deposit Models}

The Pueblo Viejo district (Figures 1 and 2) boasts open-pit production plus reserves of $30.8 \mathrm{Moz}$ gold, 185.4 Moz silver, and 590.5 Mlb copper (Borst et al., 2012, Nelson et al., 2015). Mining began in 1975, was suspended in 1998 after exhaustion of the near-surface oxide reserves, and resumed in 2012 after construction of a new plant capable of processing the underlying sulfide resource. Gold production is currently close to a million ounces per year.

Given the size of the Pueblo Viejo deposit, there is keen interest on the part of the exploration community in understanding how the ore deposits formed and, by extension, how to effectively explore for new ones. Proposed genetic models, however, vary widely with respect to both the age of mineralization and the environment of deposition. Publications in favor of an Early Cretaceous, 

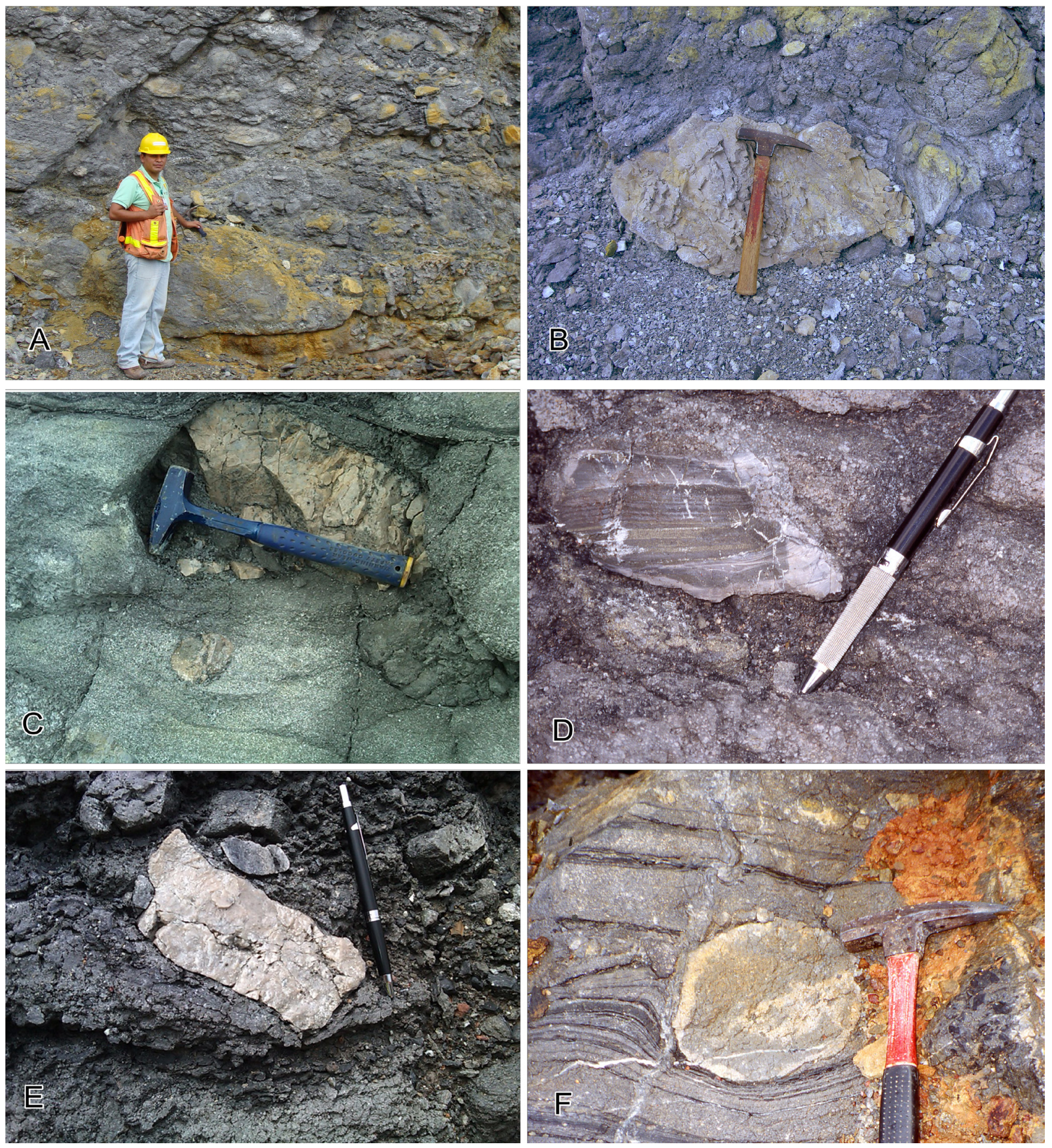

Figure 5 Outcrop photos of epiclastic sedimentary units from the Monte Negro pit. (A) Coarsely fragmental epiclastic conglomerate from the north end of the pit. (B) Hydrothermally altered (silicified) basaltic andesite clast hosted by coarsely fragmental epiclastic conglomerate, north end of the pit. (C) Silicified clast in a matrix of carbonaceous epiclastic sandstone, north end of the pit. (D) Silicified epiclastic siltstone clast hosted by carbonaceous epiclastic sandstone, central pit. (E) Silicified clast hosted by altered and mineralized carbonaceous epiclastic sandstone, central pit. (F) Bedded carbonaceous sandstone and siltstone with bedding modified by a clast of basaltic andesite. 
syn-volcanic origin include Kesler et al. (1981, 1991, epithermal deposit), Russell and Kesler (1991, maar-diatreme), Hannington et al. (1997, high sulfidation, volcanogenic massive sulfide [VMS]), and Nelson (2000, volcanic dome field). Publications in favor of a Late Cretaceous or Paleogene age include Hollister (1978, porphyry deposit) and Sillitoe et al. (2006, high sulfidation, porphyry lithocap). Readers interested in the controversy over the origin of the ore deposits at Pueblo Viejo are referred, in addition to the publications listed above, to a discussion of Nelson (2000) by Kesler and Russell (2001) and a reply by Nelson (2001) and to a discussion of Sillitoe et al. (2006) by Muntean et al. (2007) and a reply by Sillitoe et al. (2007).

Re-Os dating of sulfide mineralization from the Pueblo Viejo mine by Kirk et al. (2014) yielded an age of $111.9 \pm 3.7 \mathrm{Ma}$. Re-Os dating of molybdenite from the east flank of Loma la Cuaba by Nelson et al. (2015) yielded ages of $112.1 \pm$ $0.4 \mathrm{Ma}, 112.0 \pm 0.4 \mathrm{Ma}$, and $111.5 \pm 0.4 \mathrm{Ma}$. These ages, using a robust dating technique not easily influenced by subsequent thermal events, provide strong evidence for a mineralizing event at the Aptian-Albian boundary (112 Ma). At this time, deposition of the basal, near-shore portion of the Hatillo Limestone was already underway according to fossil assemblages and $\mathrm{Sr}$ isotope ages reviewed above.

Published descriptions of the Pueblo Viejo deposits based on field work at the ore deposits themselves (e.g., Kesler et al., 1981; Nelson, 2000) along with new evidence, presented below, from recent (since 2012) excavation at the Pueblo Viejo
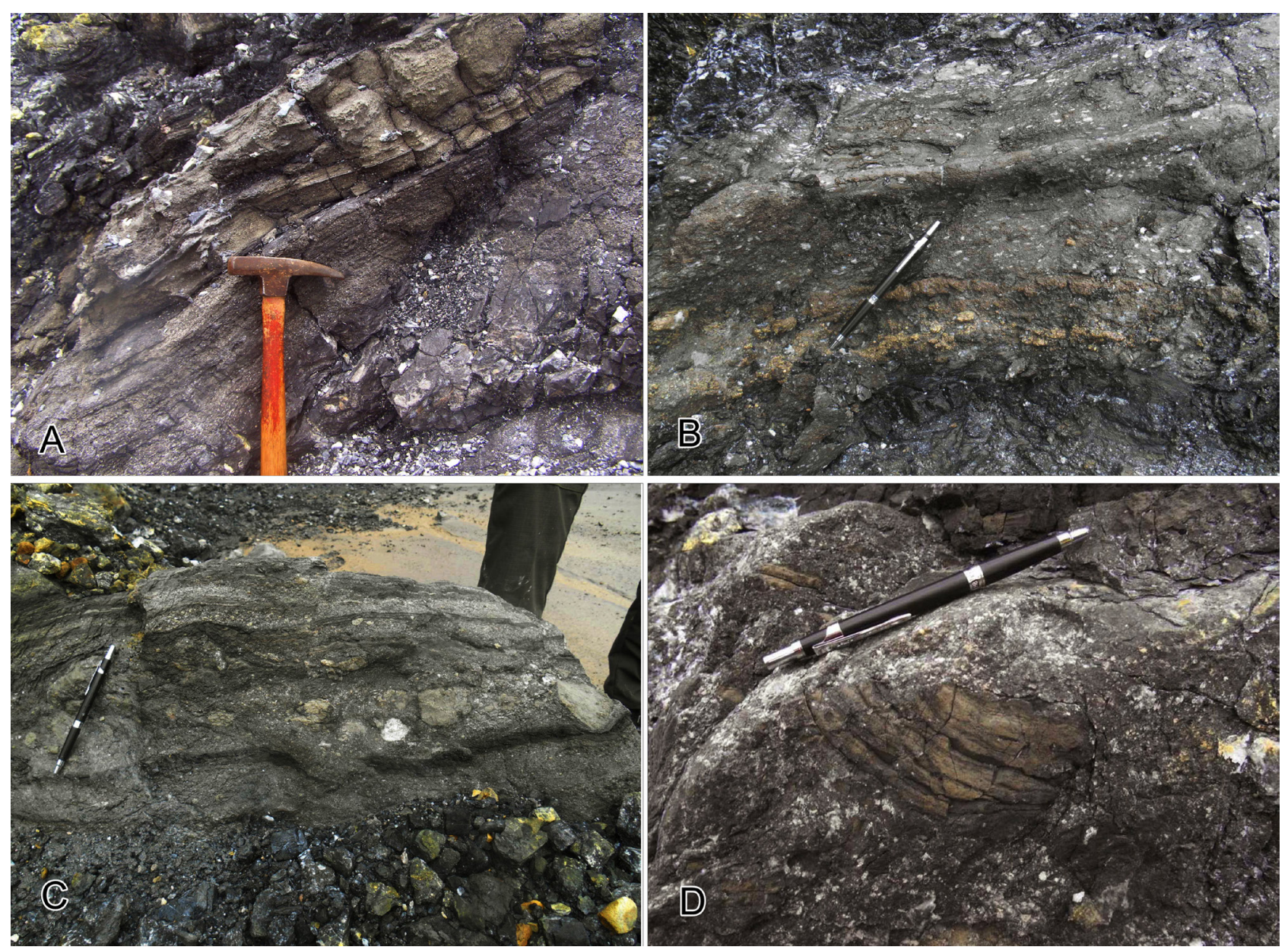

Figure 6 Volcanogenic massive sulfide (VMS) beds from the eastern margin of the Moore pit. (A) VMS bed cut by a low-angle reverse fault. (B) VMS bed with coarse pyrite. (C) VMS bed with VMS clasts. (D) Close-up of a clast of bedded VMS in a VMS matrix. 
mine indicate that the ore deposits were deposited at shallow depth, on and immediately below the seafloor, in a subsiding, intravolcanic sedimentary basin.

Hydrothermally altered clasts (Figure 5) are abundant in all of the epiclastic sedimentary host rocks exposed in the open pits. The altered clasts indicate that hydrothermal alteration was underway and hydrothermally altered rock was exposed to erosion at the time epiclastic sediments were accumulating.

Added support for a hydrothermal system open to erosion is provided by the presence of VMS beds, used here to refer to the stratiform exhalative facies of a VMS deposit (Tornos et al., 2015). VMS beds from the eastern margin of the Moore pit are shown in Figures 6A and 6B. These VMS beds contain eroded VMS clasts (Figures 6C and 6D) demonstrating that they are sediments, as opposed to replacements, and were exposed to erosion during the mineralization event. Water depth was shallow as indicated by the presence of terrestrial plant fossils (Smiley, 2002) from the same carbonaceous epiclastic sedimentary host rock section.

The VMS beds are ore bearing. Two samples, shown in Figure 6, returned 1.5 and $1.89 \mathrm{~g} / \mathrm{t} \mathrm{Au}$, 15 and $17 \mathrm{~g} / \mathrm{t} \mathrm{Ag}$, and $0.17 \%$ and $0.26 \% \mathrm{Cu}$. Although the ore deposits at Pueblo Viejo exhibit many epithermal characteristics, a genetic link with VMS deposits is certainly supported by these new (post 2012) exposures.

Hollister (1978) described Pueblo Viejo as a porphyry copper deposit. More recently, Sillitoe et al. (2006) described Pueblo Viejo as having formed in a lithocap above a Late Cretaceous or Paleogene calc-alkaline intrusion, stating that "the Hatillo Limestone appears to have acted as an impermeable seal during mineralization." This model conflicts with evidence presented in Figures 5 and 6 for a sedimentary host rock section that was exposed to erosion during mineralization. It also conflicts with Re-Os dates, published by Kirk et al. (2014) and by Nelson et al. (2015), that document an age of $\sim 112 \mathrm{Ma}$ for the ore deposits.

\section{Hydrothermal Alteration}

Sillitoe et al. (2006) provide outcrop evidence that the basal Hatillo Limestone is hydrothermally altered at Piedra Imán and at the Loma la Mina gossan (Figure 2). Previously unpublished geologic mapping (Figures 7A and 7B) supports and provides geologic context for the hydrothermal alteration reported by Sillitoe et al. (2006). The maps in Figure 7 show the extent of hydrothermal alteration in the Hatillo Limestone and the location of outcrops upon which the maps are based. Hematitic silicification at Piedra Imán primarily affects the Hatillo Limestone and, locally, is sufficiently iron rich to qualify as a gossan. Representative photos of the silicified Hatillo Limestone are shown in Figures 7C and 7D and in Sillitoe et al. (2006).

Diamond-drill hole APV11-37 (Figures 2, 7A and 7B), completed in 2011, entered hydrothermally altered Los Ranchos Formation at a depth of $48 \mathrm{~m}$, intersecting $1.5 \mathrm{~m}$ of $1073 \mathrm{ppm}$ copper and $1.5 \mathrm{~m}$ of $68 \mathrm{ppb}$ gold immediately below a faulted contact with overlying Hatillo Limestone. Throughout the remainder of the drill hole (to $357 \mathrm{~m}$ total depth) Au was below $10 \mathrm{ppb}$ and $\mathrm{Cu}$ below $200 \mathrm{ppb}$.

Sillitoe et al. (2006), in addition to outcrop evidence for hydrothermal alteration, presented geochemical evidence documenting anomalous $\mathrm{Cu}, \mathrm{Pb}, \mathrm{Mo}, \mathrm{Bi}, \mathrm{As}, \mathrm{Sb}, \mathrm{Hg}$, Se, Te, and Ba in silicified basal Hatillo Limestone at Piedra Imán. This observation is supported by observations at the Pueblo Viejo mine where, as at Piedra Imán, the basal Hatillo Limestone is, locally, hydrothermally altered. Geochemical analyses (ICP-MS) of $2 \mathrm{~m}$ intervals of core that penetrate the basal Hatillo Limestone in the Banco Cinco area (Figure 2) confirm the presence of anomalous $\mathrm{Au}, \mathrm{As}, \mathrm{Cu}, \mathrm{Zn}$, and $\mathrm{Ba}$. Six diamond-drill holes returned anomalous $\mathrm{Au}, \mathrm{As}, \mathrm{Cu}, \mathrm{Zn}$ and $\mathrm{Ba}$ from the lowermost 2 to $22 \mathrm{~m}$ of the Hatillo Limestone. Gold values reach $90 \mathrm{ppb}$, arsenic reaches $674 \mathrm{ppm}$, copper values reach as high as $210 \mathrm{ppm}$, zinc gets up to $297 \mathrm{ppm}$, and barium up to $481 \mathrm{ppm}$. These data 

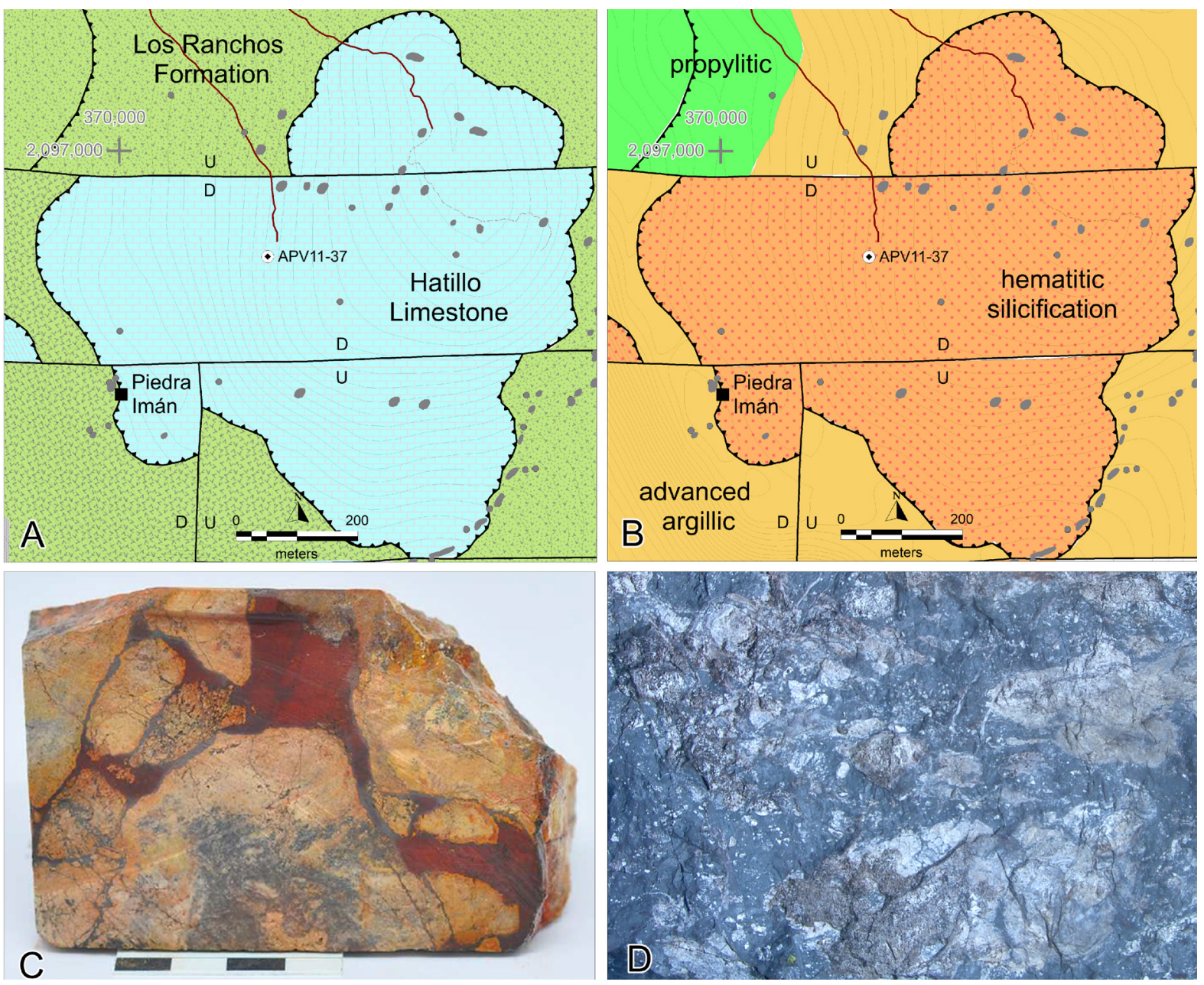

Figure 7 Distribution and hydrothermal alteration of the Hatillo Limestone at Piedra Imán (Figure 2). (A) Geologic map showing rock units; outcrop locations are indicated in gray. (B) Geologic map showing hydrothermal alteration; outcrop locations are indicated in gray. (C) Hematitic silicified Hatillo Limestone from drill hole APV 11-37 at 13.4 m; drill core measures $56 \mathrm{~mm}$ in diameter. (D) Quartzmagnetite replacement in outcrop; horizontal dimension is $25 \mathrm{~cm}$.

confirm geochemically anomalous hydrothermal alteration of the basal portion of the Hatillo Limestone.

The Pueblo Viejo and Bayaguana districts (Figure 1) exhibit similar geologic settings - volcanic dome fields mantled by pyroclastic aprons and epiclastic carbonaceous sedimentary rocks (Nelson, 2000; Escuder-Viruete et al., 2006, 2007; Nelson et al., 2011; Torró et al., 2017b). In addition, a Re-Os age for molybdenite (112.6 \pm $0.4 \mathrm{Ma}$ ) reported by Torró et al. (2017b) from the Bayaguana district (Figure 1) is close to Re-Os ages $(112.1,112.0$, and 111.5, all $\pm 0.4 \mathrm{Ma}$ ) reported by Nelson et al. (2015) for molybdenite from the Pueblo Viejo district. Mineralization in these Early Cretaceous districts has been attributed to epithermal systems transitional with VMS deposits (Nelson et al., 2011, 2015) or, alternatively, to epithermal systems transitional with porphyry deposits (Torró et al., 2017b). Regardless of the genetic model invoked, similarity of geologic setting and age of mineralization suggests that the Los Ranchos Formation may host large Au-Ag-Cu deposits, like Pueblo Viejo, at Bayaguana or elsewhere in the Early Cretaceous tholeiitic island arc that stretches from the Virgin Islands west across Puerto Rico, Hispaniola, and Cuba (Figure 1). 


\section{Low-angle Reverse Faulting, Deformation, and Metamorphism}

Schists and low-angle reverse faults are well developed in the Maimón Formation (Figure 2). Draper et al. (1996) distinguished parallel belts (El Altar and Ozama zones) of greenschist and amphibolite facies metamorphic rocks and reported that "penetrative deformation decreases progressively to the northeast."

Draper et al. (1996) went on to propose an Aptian to early Albian age for a "major deformation event" based on their description of the Hatillo Limestone as "not penetratively deformed." However, evidence presented below shows that the Hatillo Limestone has been offset by low-angle reverse faults and, especially in its basal units, exhibits penetrative deformation and recrystallization.

Bowin (1966) reported that the Hatillo Limestone "almost everywhere is slightly recrystallized" and "where the limestone has been deformed along the Hatillo thrust it is generally strongly foliated." Bowin's recognition of foliation and recrys- tallization in the Hatillo Limestone is supported by field observations in the Pueblo Viejo District (Nelson, 2000) and by diamond drilling at both the Loma la Mina gossan (Sillitoe et al., 2006) and the Pueblo Viejo mine. Figure 8 presents a series of photos from a single drill hole near Banco Cinco (Figure 2) that documents progressive penetrative deformation in the Hatillo Limestone. Stylolites (Figure 8A) give way to a well-developed mylonitic foliation (Figures 8C and 8D) above a low-angle reverse fault. Photomicrographs (Figure 9) document deformation, recrystallization, and fracture foliation in sandy to silty beds of the basal Hatillo Limestone.

Deformation and recrystallization are well developed in the underlying Los Ranchos and Maimón formations where recrystallization is clearly of metamorphic origin. Los Ranchos Formation schist (Figure 10) extends across the summit of Loma la Cuaba (Figure 2) and is particularly well developed above low-angle thrust faults. Pyrophyllite schist (Figures 10G to 10F), in particular, is well exposed on Loma la Cuaba. Although pyrophyllite is a common product of
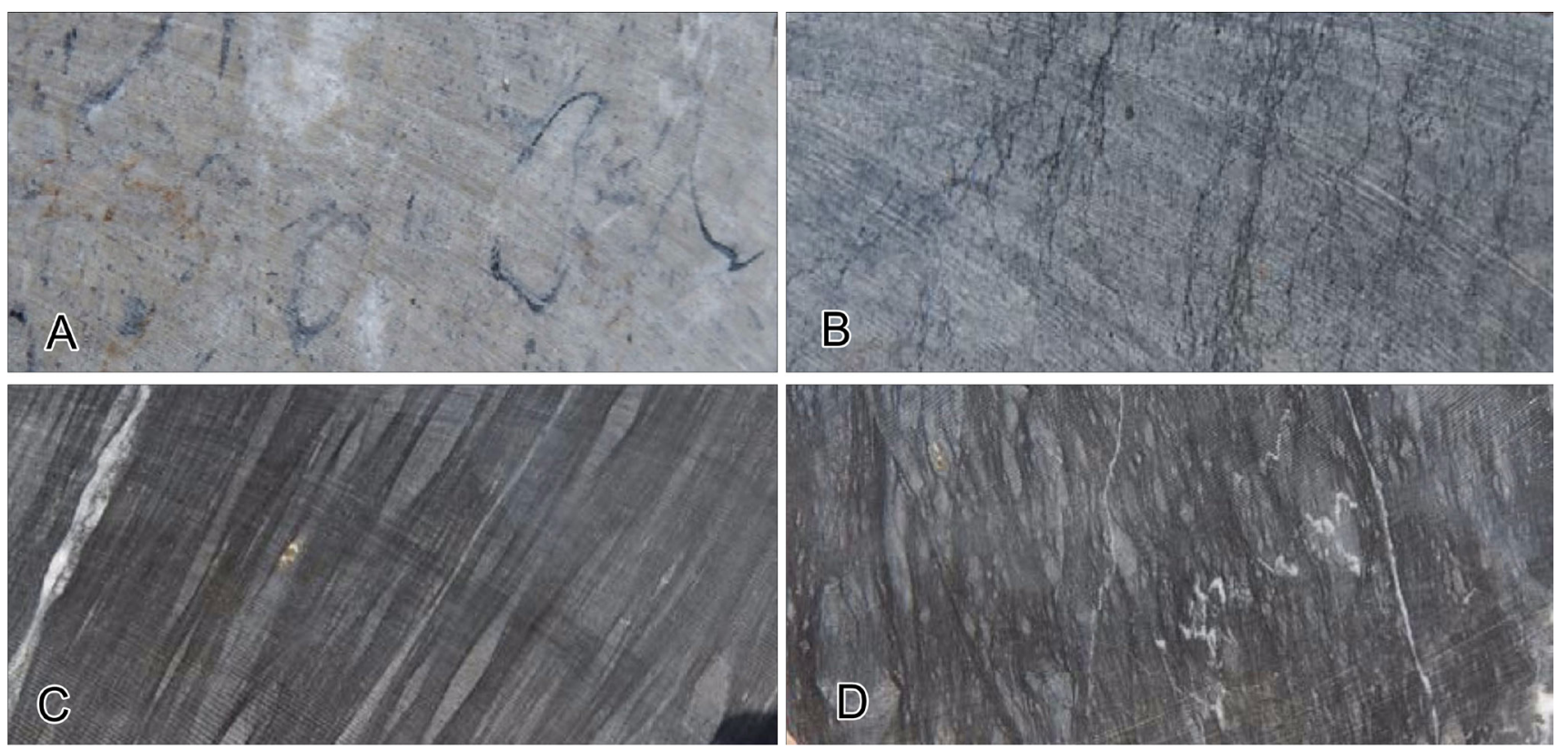

Figure 8 Progressive increase in deformation within the Hatillo Limestone above a low-angle reverse fault in drill hole LS17-199. (A) Fossiliferous (rudist-bearing) limestone at $65.8 \mathrm{~m}$. (B) Limestone with stylolites at $90.4 \mathrm{~m}$. (C, D) Fine-grained banded mylonitic tectonite with foliation defined by transposed bedding at 99.5 (C) and $103.2 \mathrm{~m}$ (D). All four photos are of drill core that measures $56 \mathrm{~mm}$ in diameter (top to bottom). 

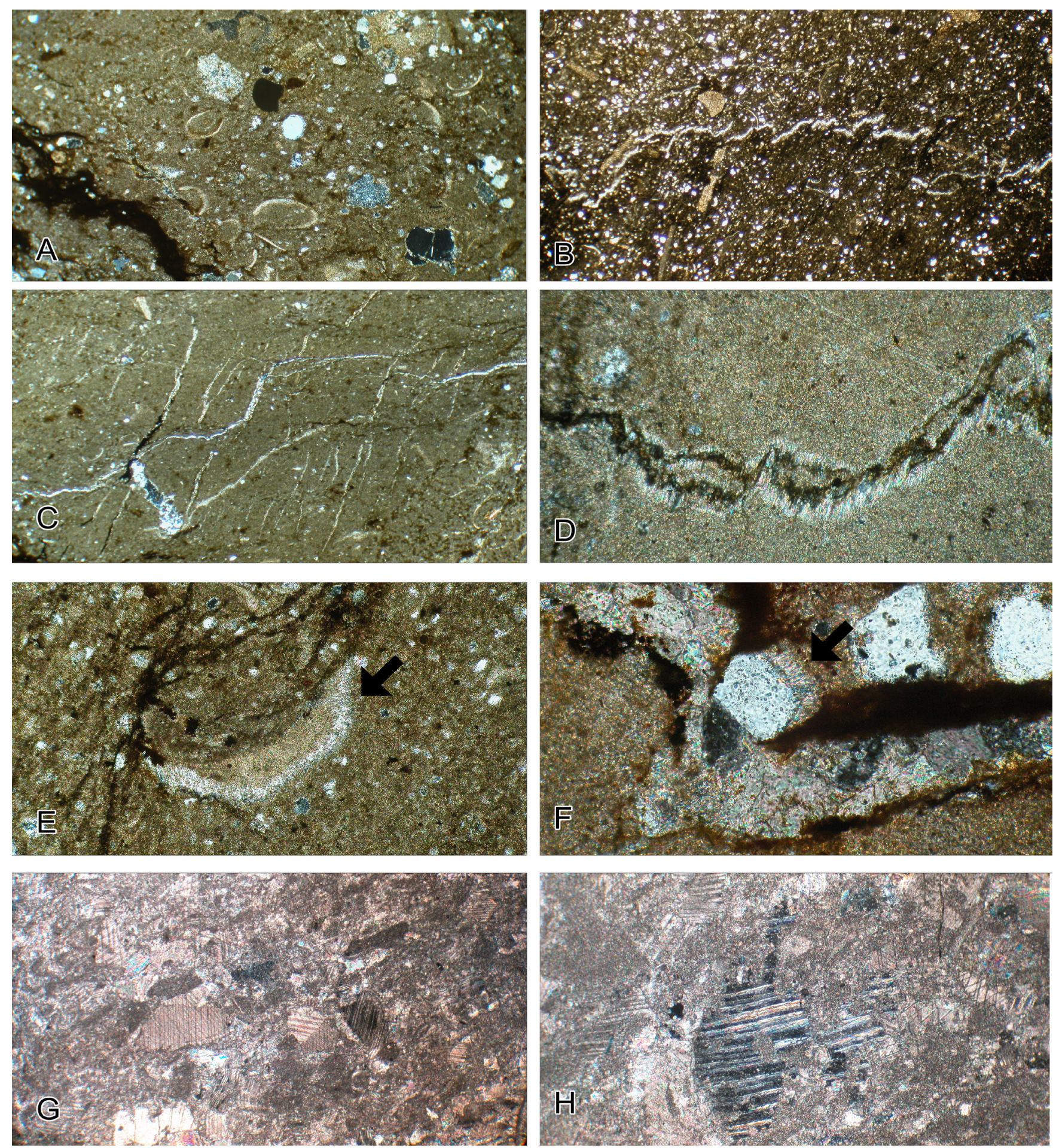

Figure 9 Transmitted light photomicrographs from the basal portion of the Hatillo Limestone, Los Quemados, showing metamorphic foliation and recrystallization. (A) Basal limestone with abundant fossil fragments including disarticulated ostracod valves (field of view $4.2 \mathrm{~mm}$ ). (B) Offsets of a calcite vein by foliation (field of view $4.2 \mathrm{~mm}$ ). (C) Calcite veinlets fill fracture foliation (field of view $4.2 \mathrm{~mm}$ ). (D) Fibrous calcite pressure shadows on a stylolite (field of view $8 \mathrm{~mm}$ ). (E ) Pressure shadow shown by arrow (field of view $2.0 \mathrm{~mm}$ ). (F) Prismatic calcite crystals forming a pressure shadow (arrow) behind a quartz grain (field of view $1.0 \mathrm{~mm}$ ). (G) Recrystallized limestone (field of view $3.4 \mathrm{~mm}$ ). (H) Limestone with recrystallized (twinned) calcite (field of view $3.4 \mathrm{~mm}$ ). 

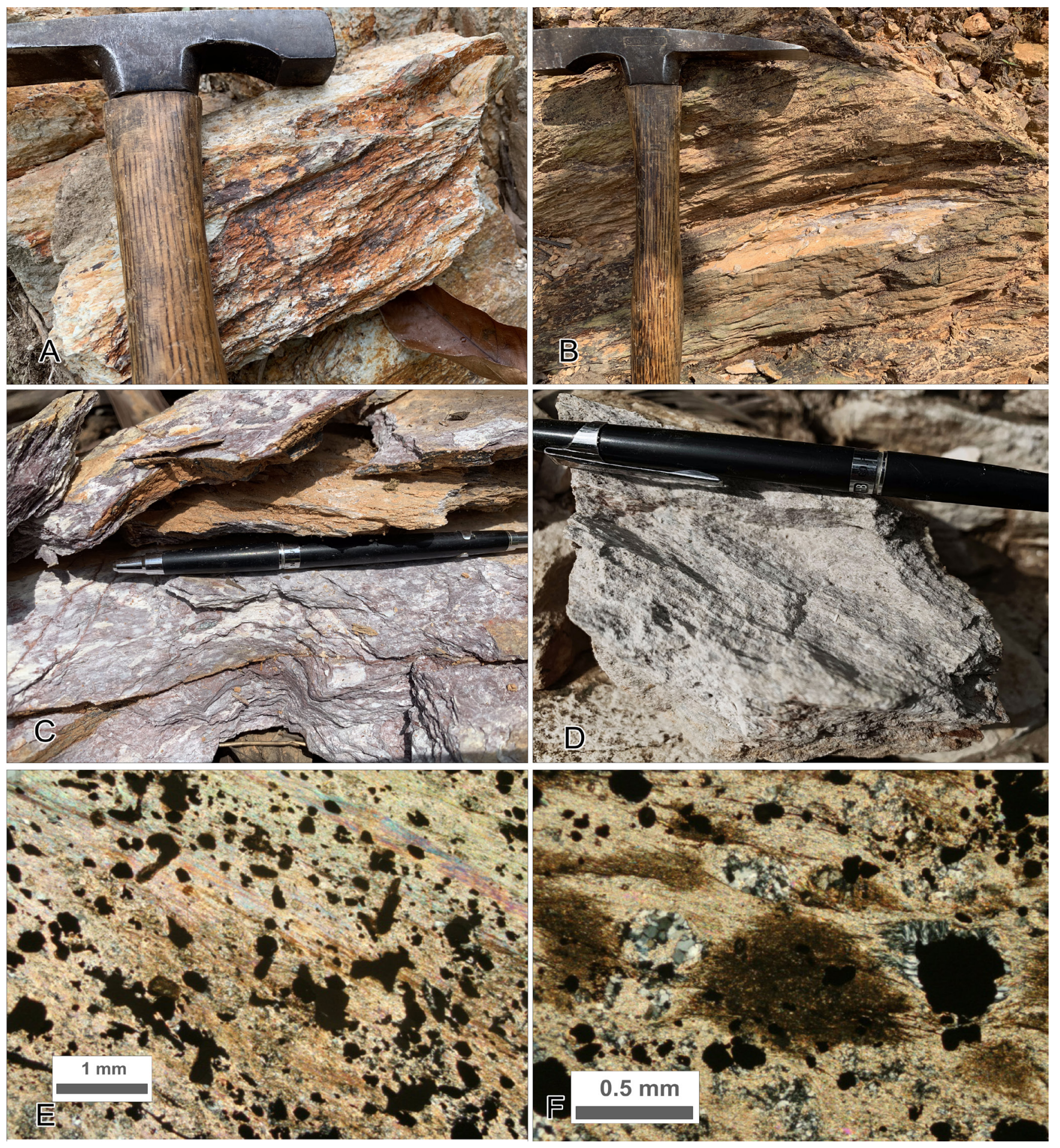

Figure 10 Photos of metamorphic foliation (schistosity) in the Los Ranchos and Maimón formations. (A) Maimón Formation schist from the town of Maimón. (B) Los Ranchos Formation schist from Loma la Cuaba (Figure 2). (C, D) Pyrophyllite schist from the Los Ranchos Formation, Loma la Cuaba. (E) Photomicrograph of pyrophyllite schist, drill hole APV 11-38 (34 m), Loma la Cuaba (photo from Torró, 2012). (F) Photomicrograph of pyrophyllite after kaolinite, drill hole APV 11-38 (72 m), Loma la Cuaba (from Torró et al., 2013). 
hydrothermal alteration in lithocaps above porphyry deposits (e.g., Sillitoe, 2010), it can also be of metamorphic origin. Hydrothermal pyrophyllite certainly exists in the Pueblo Viejo district (Borst et al., 2012; Evans et al., 2014; Torró et al., 2017a; Cardenas et al., 2018). But, where strongly foliated (Figures 10E and 10F), pyrophyllite is the product of metamorphic recrystallization, presumably of a hydrothermally altered precursor (Figure 10F).

Metamorphism in the Maimón Formation and, presumably, in the Hatillo Limestone and Los Ranchos Formation as well is Campanian-Santonian in age based on ${ }^{40} \mathrm{Ar} /{ }^{39} \mathrm{Ar}$ analysis of ferri-winchite in a sample from the Ozama shear zone of the Maimón Formation (Proenza, written communication, 2017). Ferri-winchite, first reported by Torró et al. (2016), indicates a high-pressure (8.2 $\mathrm{kb}$ at $380{ }^{\circ} \mathrm{C}$ ), presumably subduction-related, metamorphic event. Westerly-dipping subduction of proto-Caribbean oceanic crust as the Greater Antilles volcanic arc approached, and eventually collided with, the southern margin of North America was likely responsible for Late Cretaceous deformation and metamorphism.

\section{Discussion}

Geologic mapping and diamond drilling reported here from the Pueblo Viejo district provide evidence for a conformable contact between the Los Ranchos Formation and the overlying Hatillo Limestone. A transitional contact in the Bayaguana district and a measured section at the eastern end of the $100 \mathrm{~km}$ belt of Hatillo Limestone (fossil locations on Figure 1) indicate that the basal contact of the Hatillo Limestone is also conformable regionally.

Fossil assemblages from the Hatillo Limestone overlap with radiometric dates from the waning stages of Los Ranchos Formation volcanism leaving no time for a previously proposed episode of Aptian-Albian uplift and erosion. Intra-oceanic island arc volcanism (Los Ranchos Formation) and fringing reef deposition (basal Hatillo Limestone) were both active in the Pueblo Viejo district beginning in the latest Aptian and extending across the 112 Ma Aptian-Albian boundary to at least 109 Ma. The basal Hatillo Limestone was altered by the same hydrothermal system that gave rise to the 112 Ma Pueblo Viejo Au-Ag-Cu ore deposits.

Observations from the pits document the presence of hydrothermally altered and mineralized clasts in epiclastic sedimentary host rocks at Pueblo Viejo. These altered clasts indicate that the hydrothermal system was subject to erosion during hydrothermal alteration, ore deposition, and epiclastic sediment accumulation. Exhalative VMS beds in the Moore pit contain clasts of exhalative VMS and fix the location of the paleosurface during the $\sim 112 \mathrm{Ma}$ mineralizing event. Although basal units of the Hatillo Limestone are hydrothermally altered locally, ore deposit formation beneath an impermeable limestone cap is not supported by the evidence presented here.

Geologic mapping across the Pueblo Viejo district documents offset of the Maimón Formation, the Los Ranchos Formation, and the Hatillo Limestone by southwesterly dipping, low-angle reverse faults. These faults are spatially associated with development of penetrative cleavage in the Los Ranchos and Maimón formations and in the overlying Hatillo Limestone. Late Cretaceous deformation and metamorphic recrystallization post-date deposition of the Hatillo Limestone and are likely related to southwesterly dipping subduction of the Proto-Caribbean plate prior to collision with the Bahamas platform.

\section{Conclusions}

The lithology and fossil assemblage of the Hatillo Limestone varies, from bottom to top, from a near-shore reef to a deeper-water platform carbonate. Fossil assemblages and Sr isotope analyses document Hatillo Limestone deposition from late Aptian through middle Albian time. The Hatillo Limestone is in conformable contact with the underlying Los Ranchos Formation; there is no 
evidence for an intervening episode of uplift and erosion.

Abundant hydrothermally altered and mineralized clasts in epiclastic sedimentary host rocks at Pueblo Viejo indicate that (1) the hydrothermal system vented to the surface; and (2) the ore deposits were being eroded during hydrothermal alteration, mineralization, and epiclastic sedimentary host rock sedimentation. In addition, the presence of bedded volcanogenic massive sulfide (VMS) mineralization shows that the Pueblo Viejo ore deposits formed at and immediately below a shallow submarine paleosurface. These observations document a genetic link to VMS deposits, cast doubt on porphyry-related genetic models, and eliminate the possibility of an impermeable limestone cap.

Field mapping and petrographic studies provide evidence for progressive penetrative deformation and metamorphic recrystallization that increases in intensity from northeast to southwest across the Los Ranchos Formation, the Hatillo Limestone, and the Maimón Formation. The responsible Late Cretaceous tectonic event post-dates deposition of the Hatillo Limestone.

\section{Acknowledgements}

This paper benefited substantially from access to the Pueblo Viejo mine. Appreciation is extended to Barrick Gold Corporation, Precipitate Gold Corporation, and GoldQuest Mining Corporation for making analytical results from drill holes available and for permission to use photos of mine exposures and drill core. The paper also benefitted substantially from reviews by Javier Escuder-Viruete, Stewart Redwood, and an anonymous reviewer.

\section{References}

Bonilla-Rodríguez, A.J., 2014, Depositional and paleoenvironmental settings of Cretaceous limestone in the Greater Antilles: Mayaguez,
Puerto Rico, University of Puerto Rico, PhD dissertation.

Bonilla-Rodríguez, A.J., González, L.A., Walker, J.D., Santos, H., 2014, Strontium isotope $\left({ }^{87} \mathrm{Sr} /{ }^{86} \mathrm{Sr}\right)$ stratigraphy from the Coalcomana - Caprinuloidea rudist assemblage in the Greater Antilles (Puerto Rico, Dominican Republic and Jamaica): Cretaceous Research, 50, 97-109. https://doi.org/10.1016/j. cretres.2014.04.008

Borst, R., Moore, C., Villeneuve, A., 2012, Technical report on the Pueblo Viejo Project, Sanchez Ramirez Province, Dominican Republic: Toronto, Ontario, Roscoe Postle Associates, Inc., NI 43-101 technical report prepared for Barrick Gold Corporation, March 16, 2012.

Bowin, G.O., 1966, Geology of the Central Dominican Republic. A case history of part of an island arc, in Hess, H.H. (ed.), Caribbean Geological Investigations: Boulder, Colorado, Geological Society of America Memoir 98, 11-84. https://doi. org/10.1130/MEM98-p1 1

Cardenas, R., Miranda, H., Krutzelmann, H., 2018, Technical report on the Pueblo Viejo mine, Sanchez Ramirez Province, Dominican Republic: Toronto, Ontario, Roscoe Postle Associates, Inc., NI 43-101 technical report prepared for Barrick Gold Corporation, March 19, 2018.

Draper, G., Gutierrez, G., Lewis, J.F., 1996, Thrust emplacement of the Hispaniola peridotite belt: Orogenic expression of the midCretaceous Caribbean arc polarity reversal?: Geology, 24(12), 1143-1146. https://doi. org/10.1130/0091-7613(1996)024<1143:te othp>2.3.co;2

Escuder-Viruete, J., Díaz de Neira, A., Hernaiz Huerta, P.P., Monthel, J., García-Senz, J., Joubert, M., Lopera, E., Ullrich, T., Friedman, R., Mortensen, J., Pérez-Estaun, A., 2006, Magmatic relationships and ages of Caribbean island arc tholeiites, boninites and related felsic rocks, Dominican Republic: 
Lithos, 90(3-4), 161-186. https://doi. org/10.1016/j.lithos.2006.02.001

Escuder-Viruete, J., Díaz de Neira, A., Hernaiz Huerta, P.P., García-Senz, J., Monthel, J., Joubert, M., Lopera, E., Ullrich, T., Friedman, R., Weis, D., Pérez-Estaun, A., 2007, Implicaciones tectonomagmáticas y edad de las toleítas de arco-isla, boninitas y rocas ácidas relacionadas de la formación Los Ranchos, Cordillera Oriental, República Dominicana: Boletín Geológico y Minero, 118, 195-220.

Evans, L., Miranda, H., Altman, K.A., 2014, Technical report on the Pueblo Viejo Project, Sanchez Ramirez Province, Dominican Republic: Toronto, Ontario, Roscoe Postle Associates, Inc., NI 43-101 technical report prepared for Pueblo Viejo Dominicana Corporation, Barrick Gold Corporation, GoldCorp, Inc., March 27, 2014.

Hannington, M.D., Poulsen, K.H., Thompson, J.F.H., Sillitoe, R.H., 1997, Volcanogenic gold in the massive sulfide environment: Volcanic Associated Massive Sulfide Deposits: Processes and Examples in Modern and Ancient Settings: Reviews in Economic Geology, 8, 325-356. https://doi. org/10.5382/Rev.08.14

Hollister, V.F., 1978, Porphyry copper deposits of the Caribbean, in Hollister, V.F., (ed.), Geology of the porphyry copper deposits of the Western Hemisphere: New York, U.S.A., Society of Mining Engineers, American Institute of Mining, Metallurgical and Petroleum Engineers, 149-157.

Iturralde-Vinent, M.A., 1997, Meeting reports, stratigraphy and correlation of Cretaceous volcanic-arc rocks, Dominican Republic (IGCP 364): Journal of Petroleum Geology, 20(4), 489-491. https://doi. org/10.1111/j.1747-5457.1997.tb00928.x

Kesler, S.E., Russell, N., Seaward, M., Rivera, J., McCurdy, K., Cumming, G.L., Sutter, J.F., 1981, Geology and geochemistry of sulfide mineralization underlying the Pueblo Viejo gold-silver oxide deposit,
Dominican Republic: Economic Geology, 76(5), 1096-1117. https://doi.org/10.2113/ gsecongeo.76.5.1096

Kesler, S.E., Russell, N., Polanco, J., McCurdy, K., Cumming, G.L., 1991, Geology and geochemistry of the early Cretaceous Los Ranchos Formation, central Dominican Republic, in Mann, P., Draper, G., Lewis, J.F. (eds.), Geologic and tectonic development of the North America-Caribbean plate boundary in Hispaniola: Boulder, Colorado, Geological Society of America Special Paper 262, 187-201. https://doi.org/10.1130/ spe262-p187

Kesler, S.E., Russell, N., 2001, Discussion of: Nelson, C.E., 2000, Volcanic domes and gold mineralization in the Pueblo Viejo district, Dominican Republic: Mineralium Deposita, 36(5), 465-468. https://doi.org/10.1007/ s001260100157

Kesler, S.E., Campbell, I.H., Allen, C.M., 2005, Age of the Los Ranchos Formation, Dominican Republic, Timing and tectonic setting of primitive island arc volcanism in the Caribbean region: Geological Society of America Bulletin, 117(7), 987-995. https:// doi.org/10.1130/b25594.1

Kirk, J.D., Ruiz, J., Kesler, S.E., Simon, A., Muntean, J.L., 2014, Re-Os age of the Pueblo Viejo epithermal deposit, Dominican Republic: Economic Geology, 109(2), 503-512. https://doi.org/10.2113/ econgeo.109.2.503

Koschmann, A.H., Gordon, M., 1950, Geology and mineral resources of the Maimón Hatillo District, Dominican Republic: U.S. Geological Survey Bulletin, 964. https://doi. org/10.3133/b964d

Lebron, M.G., Perfit, M.R., 1993, Stratigraphic and Petrochemical data support subduction polarity reversal of the Cretaceous Caribbean Island Arc: Journal of Geology, 101(3), 389396. https://doi.org/10.1086/648231

McArthur, J.M., Howarth, R.J., Bailey, T.R., 2001, Strontium isotope stratigraphy. LOWESS version 3: Best fit to the marine Sr-isotope 
curve for 0-509 Ma and accompanying lookup table for deriving numerical age: Journal of Geology, 109(2), 155-170. https://doi. org/10.1086/319243

Mueller, A.G., Hall, G.C., Nemchin, A.A., O'Brien, D., 2008, Chronology of the Pueblo Viejo epithermal gold-silver deposit, Dominican Republic: formation in an Early Cretaceous intra-oceanic island arc and burial under ophiolite: Mineralium Deposita, 43(8), 873-890. https://doi.org/10.1007/ s00126-008-0194-2

Muntean, J., Hall, G., Kesler, S., Mueller, A., O’Brien, D., Russell, N., 2007, Pueblo Viejo high-sulfidation epithermal gold-silver deposit, Dominican Republic: a new model of formation beneath barren limestone cover - a discussion: Economic Geology, 102(4), 755-760. https://doi.org/10.2113/ gsecongeo.102.4.755

Myczynski, R., Iturralde-Vinent, M., 2005, The Late Lower Albian invertebrate fauna of the Hatillo Limestone of Pueblo Viejo, Dominican Republic: Caribbean Journal of Science, 41, 782-796.

Nelson, G.E., 2000, Volcanic domes and gold mineralization in the Pueblo Viejo District, Dominican Republic: Mineralium Deposita, 35(6), 511-525. https://doi.org/10.1007/ s001260050258

Nelson, C.E., 2001, Reply to Discussion of: Nelson, C.E., 2000, Volcanic domes and gold mineralization in the Pueblo Viejo district, Dominican Republic: Mineralium Deposita, 36, 469-471. https://doi.org/10.1007/ s001260100158

Nelson, G.E., Proenza, J.A., Lewis, J.F., LopezKramer, J., 2011, The metallogenic evolution of the Greater Antilles: Geologica Acta, 9, 229-264. https://doi. org/10.1344/105.000001741

Nelson, C.E., Stein, H., Dominguez, H., Carrasco, C., Barrie, T., Torró, L., Proenza, J.A., 2015, Re-Os dating of molybdenite from the Pueblo Viejo Au-Ag-Cu and Douvray
$\mathrm{Cu}-\mathrm{Au}$ Districts, Hispaniola: Economic Geology, 110(4), 1101-1110. https://doi. org/10.2113/econgeo.110.4.1101

Pindell,J., Keenan, L., Maresch, W.V., Stanek, K.P., Draper, G., Higgs, R., 2005, Plate kinematics and crustal dynamics of circum-Caribbean arc-continent interactions - Tectonic controls on basin development in Proto-Caribbean margins, in Avé Lallemant, H.G., Sisson, V.B. (eds.), Caribbean-South American plate interactions, Venezuela: Geological Society of America Special Paper 394, 7-52. https:// doi.org/10.1130/0-8137-2394-9.7

Russell, N., Kesler, S.E., 1991, Geology of the maar-diatreme complex hosting precious metal mineralization at Pueblo Viejo, Dominican Republic, in Mann, P., Draper, G., Lewis, J.F. (eds.), Geologic and tectonic development of the North AmericaCaribbean plate boundary in Hispaniola: Geological Society of America Special Paper 262, 203-215. https://doi.org/10.1130/ SPE262-p203

Sillitoe, R.H., 2010, Porphyry copper systems: Economic Geology, 105(1), 3-41. https:// doi.org/10.2113/gsecongeo.105.1.3

Sillitoe, R.H., Hall, D.J., Redwood, S.D., Waddell, A., 2006, Pueblo Viejo high sulfidation epithermal gold-silver deposit, Dominican Republic: a new model of formation beneath barren limestone cover: Economic Geology, 101(7), 1427-1435. https://doi. org/10.2113/gsecongeo.101.7.1427

Sillitoe, R.H., Hall, D.J., Redwood, S.D., Waddell, A., 2007, Pueblo Viejo high sulfidation epithermal gold-silver deposit, Dominican Republic: a new model of formation beneath barren limestone cover - a reply: Economic Geology, 102(4), 758-760. https://doi. org/10.2113/gsecongeo.102.4.758

Smiley, C.J., 2002, Lower Cretaceous Plants from Dominican Republic: in Caribbean Geology into the Third Millenium, Transactions of the Fifteenth Caribbean Geological Conference, Kingston, Jamaica, 119-129. 
Tornos, F., Peter, J.M., Allen, R., Conde, C., 2015, Controls on the siting and style of volcanogenic massive sulfide deposits: Ore Geology Reviews, 68, 142-163. https://doi. $\mathrm{org} / 10.1016 /$ j.oregeorev.2015.01.003

Torró, L., 2012, Hydrothermal alteration processes registered in the "Loma la Cuaba Lithocap" (Ampliacion Pueblo Viejo), Dominican Republic: a Cu-AuMo porphyry-type mineralization style?: Barcelona, Spain, University of Barcelona and Autonomous University of Barcelona, Master in Geology.

Torró, L., Proenza, J.A., Melgarejo, J.C., Carrasco, Dominguez, H., Nelson, C.E., Lewis, J.F., 2013, Alteration mineral domains under Loma la Cuaba: new insights as to the origin of the mineralization in the Pueblo Viejo District: 12th Society for Geology Applied to Ore Deposits Proceedings, 2, 590-593.

Torró, L., Garcia-Casco, A., Proenza, J.A., Blanco-Quintero, I.F., Gutierrez-Alonso, G., Lewis, J.F., 2016, High pressure greenschist to blueschist facies transition in the Maimón
Formation (Dominican Republic) suggests mid-Cretaceous subduction of the Early Cretaceous Caribbean arc: Lithos, 266267, 309-331. https://doi.org/10.1016/j. lithos.2016.10.026

Torró, L., Proenza, J.A., Camprubí, A., Nelson, C.E., Dominguez, H., Carrasco, C., Reynoso-Villafaña, R., Melgarejo, J.C., 2017a, Towards a unified genetic model for the Au-Ag-Cu Pueblo Viejo district, Central Dominican Republic: Ore Geology Reviews, 89, 463-494. https://doi.org/10.1016/j. oregeorev.2017.07.002

Torró, L., Camprubí, A., Proenza, J.A., Leon, P., Stein, H., Lewis, J.F., Nelson, C.E., Chavez, C., Melgarejo, J.C., 2017b, Re-Os and U-Pb geochronology of the Dona Amanda and Cerro Kiosko deposits, Bayaguana district, Dominican Republic: Looking down for the Porphyry Cu-Mo roots of the Pueblo Viejotype mineralization in the island-arc tholeiitic series of the Caribbean: Economic Geology, 112(4), 829-853. https://doi.org/10.2113/ econgeo.112.4.829 